\title{
THE POLITICAL ECONOMY OF SUNNI-SHI'AH CONFLICT IN SAMPANG MADURA ${ }^{1}$
}

\author{
Masdar Hilmy \\ Sunan Ampel State Islamic University, Surabaya, Indonesia \\ email:masdar.bilmy@gmail.com
}

\section{Abstract}

Many overlooked the fact that politico-economic factors played an important role behind the 2011 and 2012 Sunni-Shi'ab conflict in Sampang Madura. Some, however, argue that the Sunni-Shi'ah conflict was merely driven by theological factors. The major roots of the conflict thus were therefore the internal dimensions of religious beliefs as contained in its doctrines. As a result, the conflict can only be explained in terms of religious and theological framework. This assumption is commonly shared by the majority of Madurese Muslims by arguing that the island of Madura cannot host the believers of non-Sunni. In the aftermath of the conflict, the community of Shi'ah has been forced to seek refuge outside of the land of Madura. By doing so, many observers and the Madurese Muslims tends to have treated political and economic factors as peripheral that exacerbated the escalation of conflict. This article, however, argues vice-vers a that it is not theology, butpolitics and economy, which mainly steered the conflict. Theology played a role in exacerbating the escalation of conflict. During the conflict, religious and theological arguments were deployed as a mobilizing force in order to justify the conflict. Furthermore, the existence of Shiah community in Sampang is regarded by the mainstream Sunni community as a threat to their long domination over the socio-political structure in that region. The paper, thus, perceives the conflict as the way the local elites maintain the established mode of production. This paper is qualitative research that employs political-economy as its main approach in analyzing the data.

${ }^{1}$ The earlier version of this draft was presented at the Eighth Al-Jami'ah International Conference in Collaboration with Kyoto University: "Revisiting Sunni and Shi'ah: Thoughts, Spirituality, and Movements,” Yogyakarta, 6-8 November 2015. 
Masdar Hilmy

Para pengamat banyak tidak melihat aktor politik dan ekonomi di balik konflik Sunni dan Syiah 2011 dan 2012 di Sampang Madura. Para peneliti bahkan beranggapan bahwa konflik. Sunni-Syiah itu dilatari oleh faktor teologis. Ini artinya bahwa tiap kelompok memegang sistem kepercayaan yang berbeda. Akar utama dari konflik itu pada persoalan agama dan doketrinnya yang menyebabkan konflik. Walhasil, konflik hanya bisa dijelaskan dari kerangka keagamaan dan teologis. Asumsi ini banyak dipegang oleh mayoritas Muslim Madura dengan berasalan bahwa orang Madura tidak menerima selain Sunni, termasuk. Syiah. Setelah konflik, masyarakat Syiah dipaksa untuk mengungsi ke luar pulau Madura. Dengan begitu, banyak pengamat dan juga masyarakat Muslim Madura melihat faktor politis dan ekonomi hanya pinggiran yang memperparah konflik. Artikel ini beranggapan sebaliknya, bahwa politis dan ekonomi merupakan faktor utama. Teologi hanya memperparah saja. Pada saat konflik, faktor teologis dan agamis digunakan sebagai kekuatan untuk mobilisasi dan menjustifikasinya. Selanjutnya, keberadaan komunitas Syiah di Sampang dianggap sebagai ancaman bagi dominasi Sunni pada struktur sosio politis daerab itu. Artikel ini menganggap bahwa konflik hanyalah sebagai sarana elit lokal untuk mempertahankan dominasi sistem ekonomi. Makalah ini pada dasarnya merupakan penelitian kualitatif yang melihat fak.tor politis ekonomis sebagai pendekatan dan analisis data.]

Keywords: Sunni-Shi'ah conflict, Sampang, Madura, socio-political factors, economic factors

\section{A. Introduction}

The Sunni-Shi'ah conflict in Sampang has drawn a significant attention of some scholars. However, most of these scholarly works have overwhelmingly put their emphasis on cultural perspective to the conflict by arguing that the conflict is ideological-theological in nature, not economic-political factor. ${ }^{2}$ Despite the fact that such an assumption might applicable in explaining part of the conflict, it contains weaknesses. First, if it is about ideological-theological conflict, why is it not the case in other parts of the society, especially in some cities such as Jember and Pasuruan, East Java, where the Sunni and Shi'ah communities coexist

${ }^{2}$ See Slamet Muliono, "Syi'ah dan Masyarakat Lokal Sampang: Studi tentang Militansi Pengungsi Syi'ah dan Dinamika Masyarakat Lokal Sampang”, Research Report (Surabaya: UIN Sunan Ampel Surabaya, 2014). 
The Political Economy of Sunni-Shi'ah Conflict in Sampang Madura peacefully. Unlike in Sampang Madura, both communities in those areas avoid conflict.

Second, the Shi'ah community in Sampang in particular and Madura in general exite for a log time. It has been reported that both comunities can live together side by side since at least in the past two decades or so assumed. This proves that differences in ideology and theology cannot be as the main cause of the conflict. It is illogical that both communities are in conflict simply because of theological differences. There must be other factors beyond ideology and theology that drives conflict. Therefore, pointing the ideological-theological factor as the main cause of the conflict is simply an exaggeration.

This paper seeks to analyze the Sunni-Shi'ah conflict in Sampang Madura, seeing political economy factor; the writer perceives the conflict as the way the local elites maintain the established mode of production. In this case, the existence of Shi'ah community in Sampang is regarded by the mainstream Sunni community as a threat to their long domination over the socio-political structure in that region. Furthermore, the conflict was part of a larger scheme of electoral politics at the expense of the state's omission act towards the conflict which in the end favors the mainstream Sunni community. The reason for the state's political favoritism is clear: kiais in Madura are the vote-gatherers who have paved the way for the victory of Soekarwo-Saifullah Yusuf in the past two provincial elections (2008 \& 2013) as the governor-vice-governor of East Java.

\section{B. Sampang: Socio-religious Life}

Sampang is one of the four regencies of Madura, in addition to Bangkalan, Pamekasan, and Sumenep, located between $6^{\circ} 05^{\prime}$ and $7^{\circ} 13^{\prime}$ on the south latitude and between $113^{\circ} 08^{\prime}$ and $113^{\circ} 39^{\prime}$ east longitude. It consists of 1,233,30 km2 wide, located around $100 \mathrm{~km}$ from Surabaya to the east. It is adjacent to Bangkalan regency to the west, Pamekasan to the east, as well as Java Sea to the north and Madura strait to the south. Unlike Java where the majority of its land is suitable for paddy agriculture, most of the land in Madura in general and Sampang in particular is barren which is not suited for agriculture. ${ }^{3}$

This geographical condition is exacerbated by the low rate of rainfall during the year, which forces people to find alternative ways to

${ }^{3}$ For further account on this, see, Kuntowijoyo, Perubahan Sosial dalam Masyarakat Agraris Madura 1850-1940 (Jogjakarta: Mata Bangsa, 2002); especially the chapter 2. 
sustain economic life outside agriculture. This condition creates poverty in most of Sampang area, especially in the area of conflict, futher deteriorated by the steadily population growth. Some of the papulation prefer to go outside of Sampang for migration, ${ }^{4}$ such as Surabaya and Jakarta, among the most favorite cities to which the community of Sampang mostly is heading. A significant number of Sampang community goes to other island such as Kalimantan and even Malaysia and Saudi Arabia as the destination for making better life.

Viewed from several key indicators, such as poverty index, Human Development Index (HDI), income per capita, Sampang is the lowest compared to other three regencies in Madura: Sumenep, Bangkalan and Pamekasan. First of all, based on the data released by The Centre for Statistical Bureau (Biro Pusat Statistik/BPS) in 2007, Sampang comprises the poorest regency in Madura with the income per capita Rp. 4.789.960,00 the second lowest after Pamekasan (Rp. 4.615.107,00). Secondly, the HDI of Sampang is the lowest with the following order: Sumenep (62,15), Bangkalan (61,94), Pamekasan $(61,62)$, and Sampang $(55,77) .^{5}$

Socio-religiously speaking, the majority of Madurese community is Muslim, only a small minority are non-Muslims. The religious identity of Madurese community is identical with that of Nahdlatul Ulama (NU). It is reported that no single Madurese Muslim converts to non-Islam. The non-Muslim Madurese therefore is not of Madura origin. ${ }^{6}$ They are usually not Madura-born origins and become Madurese due to migration to the island. Being a Muslim in Madura, including in Sampang, is a matter of symbolic identity rather than a substantive piety. Religion in its symbolic sense occupies the most significant aspect of Madurese culture. Insulting Islam in this context can be translated into insulting the very idenity of being Madurese, but not the other way around.

There are abundant religious festivals throughout the year as the standard of symbolic pietism among the Madurese community. They have a great deal of traditional rituals such as Slametan for memorizing the deceased ancestors which are usually held in every Thursday night

${ }^{4}$ Huub de Jonge, Garam, Kekerasan dan Aduan Sapi: Esai-esai tentang Orang Madura dan Kebudayaan Madura (Yogyakarta: LKiS Group, 2012), pp. 77-10.

${ }^{5}$ Biro Pusat Statistik, Sampang dalam Angka (Sampang: BPS Kab. Sampang, 2008).

${ }^{6}$ Imam Bonjol Juhari, "Gerakan Sosial Islam Madura: Studi Gerakan Protes Islam Sunni terhadap Ideologi Syi'ah di Sampang”, Master Thesis (Surabaya: UIN Sunan Ampel Surabaya, 2014), p. 114, http:/ / digilib.uinsby.ac.id/1213/, accessed 28 Sep 2015. 
The Political Economy of Sunni-Shi'ah Conflict in Sampang Madura (malam Jumat). There are other festivals of Slametan for venerating the sufi figures such as Qadiriyah founder, Abd al-Qadir al-Jilani, the Slametan for venerating the death of Hussein, the grandson of the Prophet, the veneration of Abu Bakar in the month of Safar in the Hijriyah calendar. In the month of Rabi'ul Awwal there is a bigger Slametan festival for venerating the birth of the Prophet. In the next month, Rabi'ul Akhir, there is another Slametan called sedekah arosol (almsgiving for the Prophet). On the 27 Rajab there is Slametan for celebrating Isra' Mi'raj (the heavenly ascendant of the Prophet to receive the five-daily prayers from God). During the month of Sya'ban the villagers hold a night long festival to raise prayers asking for prosperity, health and good life. ${ }^{7}$

In addition to religious function, those festivals play a central role in strengthening the social solidarity among the community. Kiais and santris are of the important figures behind all of those festivals without whom the festivals are meaningless. They give meanings to all of those festivals through their skills in leading the rituals which are mostly recited in Arabic language. Due to their expertise in leading rituals and festivals, kiais receive cabisan (enveloped money) as the charity given by the community. The rituals and festivals even serve as the income source for kiais, giving them an important economic buffer zone which can support financially the existence of pesantren and their families. ${ }^{8}$

Culturally speaking, the ethic Madurese has its own unique culture that adopts a patrimonialistic culture. Under such a culture, each person obys the most respected persons in the society as follows: buppa', babbu, guru, rato (father, mother, teacher and the man of government). ${ }^{9}$ Upon those figures every Madurese must rest his/her allegiance hierarchically that creates routine and normative cultural tradition. For a Madurese, to live properly means that one can hardly avoid such a cultural tradition, forming a collective framework for action that binds every Madurese as a collective idenity without which a Maduree person means nothing. Violation of such a value will result in a social and cultural punishment in the society.

7 Ibid.

8 Syamsul Arifin and Muhammad Junaedi, "Konstruksi Sosial Masyarakat Syi'ah dan Sunni di Sampang, Madura", in Hak Asasi Manusia untuk Kebebasan Beragama dan Berkeyakinan di Indonesia: Keniscayaan, Kenyataan dan Penguatan, ed. by Syamsul Arifin (Madang: Pusat Studi Agama dan Multikulturalisme [PUSAM] Program Pascasarjana UMM, 2014), p. 350.

9 A. Latief Wiyata, Carok: Konflik Kekuasaan dan Harga Diri Orang Madura (Yogyakarta: LKiS, 2002). 


\section{Non-governing Elite: Position of Kiai}

It is under such a scheme that kiai (religious person, mostly from pesantren) plays a cetral role in the socio-religious life of Madura. ${ }^{10}$ The position of kiai in this context is parallel to that of guru in the hierarchy of obedience. The obedience to religious guru, i.e. kiai, weighs more than a non-religious guru. It is due to this reason that more people in Madura are willing to send their children to pesantren (or madrasah) rather than in secular schools. Pesantren or madasah is considered to be able to salvage their children in this world and the hereafter. That is why almost everyone in Madura is happily associated with anything related to pesantren.

Within the structure of Madura's socio-cultural tradition, kiai and blater (thug) are two most respected figures in each domain. While kiais are respected because they are regarded as the heirs of the Prophet and the source of religious truth, blaters are respected for their strength, skills and intelligence in building domination over the rest of society. In Rozaki's words, both can be described as "twin regimes" in Madura. Both are influential in building and maintaining the socio-political web of power in the society. In doing so, both can go hand-in-hand in a team fied by a common interest among them. ${ }^{11}$

From the description above, it can be understood that the position of kiai forms a hierarchy of elite in the leadership of Madurese community. He is respected by the community because of his charisma in Weberian sense. ${ }^{12}$ The level of his charisma increases as kiai enters the reality of formal state instittution such as a regent or a member of legislative body, for instance. This is the case with the regents of Bangkalan, Sampang and Sumenep where the regents are kiais. ${ }^{13}$ In this case, they can accumulate

${ }^{10}$ For further information of the kiai's role in Madura, see Abdur Rozaki, Menabur Kharisme Menuai Kuasa: Kiprab Kiai dan Blater sebagai Rezim Kembar di Madura (Yogyakarta: Pustaka Marwa, 2004).

11 Abdur Rozaki, "The Social Origins and Political Power of Blaters (Thugs) in Madura", Kyoto Review of Southeast Asia (12 Nov 2009), http://kyotoreview.org/ issue-11/the-social-origins-and-political-power-of-blaters-thugs-in-madura/, accessed 28 Oct 2015.

12 Max Weber, On Charisma and Institution Building, ed. by S.N. Eisenstadt (Chicago and London: The Univ. of Chicago Press, 1968), pp. 284-94.

13 Almost all regents in Madura are kiai or associated with pesantren background. Makmun Ibnu Fu'ad, the regent of Bangkalan and the son of the former regent of Bangkalan, Fu'ad Amin Imron, is the great grandchild of Syaikhona Kholil, the grand syaikh for almost all kiais in Java. Abuya Busyro Karim, the current regent of Sumenep, is also kiai from pesantren background. He himself leads the Pesantren Al-Karimiyah Gapura Sumenep. Fannan Hasib, the current regent of Sampang, is also kiai in his 
The Political Economy of Sunni-Shi'ah Conflict in Sampang Madura

the power of the two sources: formal-authoritative power source and non-formal spiritual one. Despite the fact that the regent of Pamekasan is not kiai, he is well supported by pesantrens. This indicates that religious authorities do matter for the majority of Madurese Muslims.

Following Pareto's theoretical framework, kiai and bureaucratic figures comprise the elite of the community. ${ }^{14}$ While the regents can be classified as the ruling elite, the kiais are non-governing one. In the structure of Madura's social tradition, the relationship between the lay persons and their elites forms a hierarchical as well as patrimonialitic pattern of loyalty. Particularly in matters of religion, the loyalty of the lay persons to their kiais is not optional; it is a must and non-negotiable one. It is of a common belief among the Madurese that-following the Prophetic saying - the kiais are the heirs of the Prophet. Along with this common belief, the Madurese community imagines the kiais to have the highest position in the hierarchy of social structure, whose legal opinions on religious matters are binding people.

As the non-governing elite, kiai sometimes expands his role in the society beyond his traditional role as religious leader. He gives patronage to his former students in economic business or politics. By this definition, it does not necessarily mean that the kiai has dropped his traditional role as religious leader in society. With such an expanded role, the position of kiai is stronger in society. The expansion of the role of kiai is possible due particularly to the fact that the former students usually maintain their relationship with their kiai even after graduation. The former students usually rely on his kiai as the spiritual advisor for their worldly affairs in return for economic or financial support for the pesantren. As a result, graduates of pesantren serve as one of the financial sources that sustain its fondation. ${ }^{15}$

Another form of expansion in the role of kiai in Madura can also be seen from the involvement of kiai in local electoral politics. The involvement of kiai can be two forms: direct and indirect types. In the case of direct involvement, some kiais in Madura run for a regent or member of the parliament. The electoral democracy makes the region. It is only Ahmad Syafi'i, the current regent of Pamekasan, who is not kiai, but has a close relationship with pesantren in Pamekasan.

${ }^{14}$ Vilfredo Pareto, The Rise and Fall of Elites: an Application of Theoretical Sociology (London: Bedminster Press, 1968), pp. 42-58.

15 Jatim, "Konflik Sunni-Syi'ah Sampang Madura: Telaah Fenomenologis terhadap Patrimonialisme Budaya Politik”, Master Thesis (Surabaya: UIN Sunan Ampel Surabaya, 2014), p. 57, http://digilib.uinsby.ac.id/1328/, accessed 28 Sep 2015. 
relationship between politics and the world of kiai or pesantren becomes closer. The personality of kiai, to a greater extent, helps to boost his victory in local electoral contests even though it is not an absolute guarantee.

In the case of indirect kiai's involvement, the position of kiai is usually exploited by the elites of political parties as the vote-gatherers during the local elections. They are not running for themselves; rather, they give their political support for particular candidates who run in the election. The kiais involvement of this type might not be driven by economic or political motifs. Ideological motif sometimes drives the kiais involvement in the local politics. They exert whatever necessary to help candidates to win the election. The kiais are behind the scene who support particular candidates whose ideology is leanings are in line with the kiais interests. What is meant by the ideological motif in this context is kiais imagination about an ideal community based on religious arguments.

\section{Shi'ah Community in Sampang}

The Shi'ah community in Sampang had not existed until the family of Makmun, a local kiai in the village Karang Gayam, Sub-district Omben, Sampang, introduced this sect within a limited circle- his family and his surrounding - in the 1980s. ${ }^{16}$ He was reportedly impressed by the 1979 Islamic revolution in Iran and admired its leader, Ayatollah Khomeini, particularly in relation to his effort in toppling down the previous regime of Syah Reza Pahlevi. This motivates him to learn more about anything related to Shi'ah and its teachings. Makmun was nevertheless aware that teaching Shi'ah in to his surroundings would be mission impossible due to the fanatic subscription of the community to Sunni (NU) in general.

As it has been, and still is, the case, that the community of Madura is characterized by patrimonialism in almost areas of life, particularly in religion. The community leaders are respected due to their charisma, which is handed down hereditarily from generation to generation. They are respected because of traditional charisma, not their intellectual capacity. This situation has been Makmun's concern. In his view, such a leadership will not result in the betterment of society; it will instead cause the accumulation of power and wealth in limited family of kiai. They are not concerned with the poor condition of society; poverty, illiteracy,

${ }^{16}$ Arifin and Junaedi, "Konstruksi Sosial Masyarakat Syi'ah”, pp. 345-46; Jatim, "Konflik Sunni-Syi'ah", p. 54; Juhari, "Gerakan Sosial Islam Madura”, p. 122. 
The Political Economy of Sunni-Shi'ah Conflict in Sampang Madura and other social illnesses.

The uneasiness of Makmun grew when he saw the backwardness was everywhere in Sampang. In his opinion, the community suffered from backwardness in all aspects of life as a result of hereditary leadership which did not accommodate merit-based leadership. The first type of leadership is concerned with private interests of power and wealth accumulation. They are not concerned about the interest of public life. The possibility of vertical mobilization among the kiais to be formal leaders such as regent is higher than the lay community or those with no pesantren background. They usually use their biological factor as a stepping stone towards such a mobilization. ${ }^{17}$ The social condition above motivates Makmun to transform the society through religious reform, and he sees Shi'ah as one of the liberating forces.

From the beginning, Makmun did not spread his Shi'ah ideology openly. As an initial stage, in 1983 he sent his four kids_-Iklil Milal, Tajul Muluk, Roisul Hukama and Ummi Hani-to study in Yayasan Pesantren Islam (YAPI), a Shi'ah-affiliated pesantren in Bangil Pasuruan. YAPI is a pesantren that adopts Shi'ah Ja'fariyah school of thought. Makmun's children graduated from this pesantren in 1991. Of these four, it is only Tajul Muluk who continued his study in Saudi Arabia in 1993. Due to funding problem, he finally dropped out from his school but continued to live there as a worker and went back to Indonesia in 1999.

Upon his arrival in Indonesia, he lived in sub-village (Dusun) Nangkernang, the village Karang Gayam, Sampang. Makmun's family and the community of surroundings welcomed him. One of Makmun's students endowed his piece of land to Makmun's family for building a pesantren. In 2004 the people who were taught by Tajul Muluk were hand in hand in building his house which functions as pesantren as well, equipped with a praying house (mushalla) and several classrooms for instruction. This small pesantren was named "Misbahul Huda," and the teachers were Tajul Muluk and his brothers and sister who studied in the Pesantren YAPI Bangil. ${ }^{18}$

Different from his father, Makmun, who taught his family and the surrounding community in secrecy (taqiyah), Tajul Muluk took an open approach in teaching Shi'ah to the wider community. Tajul is friendly and generous in assisting his fellow humans in need, as well as his option not to receive money (cabisan) from the community after giving

17 Jatim, "Konflik Sunni-Syi'ah", p. 56.

18 Juhari, "Gerakan Sosial Islam Madura", pp. 123-24. 
religious sermons, makes him as a young popular preacher who appeals sympathy and support from wider audience. This makes him easier to propagate Shi'ah thoughts to the public. It is only within three years, a significant number of people in Karang Gayam, his village, and Blu'uran, neighboring village, has become his loyal followers. Up to 2011, when the conflict exploded, there are 584 Shi'ah followers in his region. ${ }^{19}$

The development of Tajul Muluk's propagation was finally responded by the local kiai. It is Ali Karrar Shinhaji, the leader of Pesantren Daut Tauhid, Desa Lenteng, the Sub-District of Proppo, Pamekasan, who is also Makmun's close relative, gave response to Tajul Muluk's Shi'ah missionary. For Karrar, Shi'ah is a defiant sect in Islam. A lot of fellow kiais showed the same response to Tajul Muluk. They however could not stop Tajul Muluk's activities because they paid homage to his father, Makmun, who passed away in 2004. After Makmun passed away, there was nobody who gave direct protection to Tajul Muluk's activities.

\section{E. Waves of Resistance}

As Tajul Muluk had wider audience, resistance from the rest of the community, especially from religious elites, starts to appear. Following David G. Bromley (2002), as quoted by Arifin \& Junaedi, the resistance has undergone three major stages; latent tension, nascent conflict, and intensified conflict. ${ }^{20}$ At the first stage, conflict takes the form of misunderstanding and prejudices between the two parties. In the context of Shi'ah community in Sampang, the period 2004 to 2011 can be classified as the latent tension where the followers of Shi'ah and the opponents were in lurking to one another in prejudices.

In the middle 2005, Ali Karrar Shinhaji held a big religious gathering (pengajian) in the village Karang Gayam which was reportedly attended by thousands of audience and kiais in the Sub-District Omben Sampang. This gathering was designed as counterbalance to the propagation of Shi'ah carried out by Tajul Muluk and his family in the same area. Even though in this pengajian Ali Karrar did not use sarcastic and provocative speech in admonishing the Shi'ah as a defiant set, he already warned the audience that there was a threat from Shi'ah in that area. Since then, the news about the existence of Shi'ah in the village Karang Gayam has soon

\footnotetext{
${ }^{19}$ Ibid., p. 187.

20 Arifin and Junaedi, "Konstruksi Sosial Masyarakat Syi'ah", p. 345.
} 
The Political Economy of Sunni-Shi'ah Conflict in Sampang Madura spread over the public in the Sub-District Omben Sampang. ${ }^{21}$

The provocation of hate speech against the Tajul Muluk-led Shi'ite community was since then intensified. On 26 February 2006, a meeting among the kiais of Madura initiated by Kiai Ali Karrar Shinhaji was held under the organization of BASRA (Badan Silaturahmi Ulama se Madura). ${ }^{22}$ This meeting was also attended by the head of regent Fadilah Budiono and the head of Ministry of Religious Affairs Sampang, Imron Rosyidi. This meeting was held at the house of Sya'bi (local elite of Omben), designed as an "inquisition" of Shi'ah ideology in Sampang. For this purpose, Tajul Muluk was invited to clarify all accusations against Shi'ah as a defiant sect. In that meeting, Tajul came with his followers bringing all references to deliver to the attendance, but all kiais seemed to make this meeting to force Tajul to return to Sunni Islam (NU) and stop all his activities in propagating Shi'ah. Tajul was given a week to answer the ultimatum. ${ }^{23}$

The next meeting was held a week later, on 5 March, 2006, by Abdul Wahhab Adnan, a local kiai together with the head of The Indonesian Ulama Council (MUI) Sampang, Kiai Mubassyir and the head of Police office of Omben. The meeting took place in at the mosque Landeko' Karang Gayam, the house of Tajul Muluk's grandfather, Kiai Nawawi. This meeting was attended by Tajul Muluk and it was formally entitled Forum Musyawarah Ulama (FMU). All participants listened to Tajul Muluk's answer about the existence of Shi'ah. Tajul used the meeting to defend his belief that Shi'ah is not a defiant sect and he argued that it is widely acknowledged in the world of Islam. He was not willing to quit his belief in Shi'ah. ${ }^{24}$

As the FMU failed to convert Tajul Muluk into Sunni, this forum has come into decision as follows:

To urge the leader of Shi'ah Ja'fariyah, Tajul Muluk, to convert to Ahl al-Sunnah wa al-Jama'ah and the pious predecessors in order to avoid the physical and ideological clash among the community which is likely to happen. And because Tajul Muluk has rejected all offers given by FMU, then FMU did not take any responsibility to whatever can happen and render instead this problem to the concerned institution. FMU recommends the MUI in four Districts in Madura release a legal opinion

21 Interview with Iklil al-Milal, Sidoarjo, 12 April 2014.

${ }^{22}$ Juhari, "Gerakan Sosial Islam Madura”, p. 139.

23 Jatim, "Konflik Sunni-Syi'ah", p. 65.

24 Ibid., p. 66. 
(fatwa) on the danger of defiant sects, including Shi'ah that questions the authenticity of the Qur'an, the righteousness of Sahabat (Companions of the Prophet) and exaggeration in ahl al-bait (the Prophet family). ${ }^{25}$

In April 2007, on a mawlid (the commemoration of the Prophet's date of birth) season, Tajul Muluk invited the community to commemorate the mawlid in the village mosque, in order not to burden the community, especially the have-nots. The mawlid festivals in the village are usually carried out in every house by inviting the kiai or teachers (ustaz) to give religious sermons. According to Tajul, this tradition is of course burdensome for the community. For the poor, sometimes they have to borrow some money to finance the ritual. The mawlid season becomes the harvest time for local kiais because each house is in a competition to invite speakers from kiais or ustaz and they have to give cabisan to the kiais at least Rp. 50.000,00 for each kiai. This has become the tradition of Muslim community in Sampang, not only in the village Karang Gayam and Blu'uran. ${ }^{26}$

Since Tajul sees the mawlid tradition is burdensome, he initiated a unified commemoration of the mawlid festival in a single mosque which is supported by most members of the community collectively. Tajul's idea of holding a unified mawlid festival was spread over the community outside of the village. In response to Tajul's idea, the community was provoked to block the ways to the mosque by bringing weapons such as sickles (celurit) and wooden sticks (pentungan). They besieged all accesses and blockaded all roods to the village Karang Gayam. In order to avoid physical clash, troops from TNI and police were deployed to safeguard the house of Tajul Muluk. The mawlid festival was finally held, but only attended by limited family members and pupils of Tajul Muluk. ${ }^{27}$

In response to all Tajul Muluk's activities, a bigger meeting was initiated on 26 October 2009 involving MUI Sampang, PCNU Sampang, the Chairman of DPRD Sampang, the Chairman of Depag Sampang, Bakesbangpol (Badan Kesatuan Bangsa dan Politik) Sampang and a great number of kiais in Sampang. This meeting was held at the office of Police Sampang. This meeting produced five points signed by Tajul Muluk:

First, Tajul Muluk is not allowed to carry out rituals and propagation

25 "Laporan Investigasi dan Pemantauan Kasus Syi'ah Sampang", Report, (Surabaya: Kontras), p. 4, http://kontras.org/data/Laporan\%20Investigasi $\% 20$ Syiah\%20di\%20Sampang.pdf, accessed 17 Sep 2015.

26 Jatim, "Konflik Sunni-Syi'ah", p. 66.

27 Interview with Mulyono, 20 April 2014. 
The Political Economy of Sunni-Shi'ah Conflict in Sampang Madura activities related to Shi'ah because this has brought troublesome for the community. Second, Tajul Muluk is not willing to carry out rituals, propagation and dissemination of the sect in the District Sampang. Third, if he keeps carrying out the rituals and propagation activities Tajul Muluk is willing to be brought to justice. Fourth, the institutions of MUI, NU and NGOs in the District Sampang will keep eye on the sect. Fifth, the organizations of MUI, NU and NGOs in the District Sampang are ready to curb the chaotic situation in the community dialogically and anarchically as long as Tajul Muluk has obeyed the points 1 and $2 .^{28}$

However, the letter of agreement made on 26 October 2009 seems ineffective because it cannot stop all Tajul Muluk's activities. He keeps observing and teaching Shi'ite to the public. Due to this reason, the kiais and community sent a letter to the Regent of Sampang, the head of police office of Sampang, the Chairman of local parliament and the head of district court Sampang, signed by tens of local kiais and hundreds of community leaders.

In response to that letter, the head of office Sampang invited all those who signed the letter on 11 April 2011 and Indonesia's general headquarter of police (Mabes Polri) in the Pesantren Darul Ulum Gersempal, Omben, Sampang. The meeting came to the following agreements: 1) Tajul Muluk has to leave from Madura; 2) He must not campaign his Shi'ite teachings to the community of Madura; 3) All of his followers must return to the Sunni (NU) religious gatherings in order to be trained over again. Related to this agreement, on 28 May 2011, the MUI of Madura held a meeting resulting in the following two points: 1) to stop all activities of Shi'ah in Karang Gayam; and 2) recommend that Tajul Muluk as the leader of Shi'ite community to move to Malang, precisely in Lembah Dieng Block N2, Malang city. ${ }^{29}$

The resistance of kiais and community in Madura to the Shi'ah community reaches its culmination on 29 December 2011, when the Pesantren Darul Huda as the center for Tajul Muluk's activities in the sub-village Nangkernang, village Karang Gayam, Omben, Sampang, was finally burnt by the masses. All properties of the house and building were flatted with the ground. The masses came from five villages in Omben, none of whom thus far brought to trial.

As a result of this persecution, 306 members of the Shi'ah community were evacuated to the office of the Sub-district Omben.

28 "Laporan Investigasi", p. 5.

29 Jatim, "Konflik Sunni-Syi'ah", p. 69. 


\section{Masdar Hilmy}

Since the office cannot accommodate the refugees properly, they were evacuated again to the sport center of Sampang. Most of the refugees were dominated by female and children. The total number of Shi'ah followers in the sub-village Nangkernang is 584 persons or 135 heads of family. ${ }^{30}$ It means that the evacuation was not carried out to all members of Shi'ah community in that sub-village. In that persecution, nobody was injured nor killed because the masses only targeted the physical buildings, not humans.

The persecution of Shi'ah community does not stop there. A bigger scale of persecution occurred on 26 August 2012 that claimed lives of the Shi'ah community. At around 8 o'clock, a great number of masses armed with sharp weapons such as celurit and swords, as well as wooden sticks, have gathered at Nangkernang to blockade the departure of the Shi'ah community children to some pesantrens outside Sampang such as Bangil Pasuruan and Pekalongan, Central Java. The persecution has claimed one life of the Shi'ah follower, Hamama (50 years) and ten others were critically injured. The masses also burnt 48 houses of the Shi'ah followers. This persecution also resulted in the loss of properties and cattle which was confiscated by the anti-Shi'ah masses.

This time the police arrested the persecutors and brought them to trial. The provincial court of Surabaya has pronounced varied sentences of imprisonment to them from 6 months to 4 years depending on the degree of crime they have perpetrated. As a result of this persecution, and in order to avoid the claim of more lives, 168 Shi'ah followers were finally evacuated to Puspa Agro Sidoarjo. This evacuation was facilitated by the local government of Sampang and the provincial government of East Java employing 3 police trucks and 2 buses, accompanied by 3 escort cars. ${ }^{31}$

\section{F. The Economy of Conflict: Maintaining the Established Mode of Production}

At the surface to society's structure, one may find the Shi'ah-Sunni conflict as an ideological contest between the two. However, when scrutinized more deeply, the conflict follows the structure of production mode wrapped in the argument of cultural essentialism, as though culture

\footnotetext{
${ }^{30}$ Juhari, "Gerakan Sosial Islam Madura”, p. 187.

31 Ibid., p. 189.
} 
does matter for each conflicting party. ${ }^{32}$ In line with this argument, on the surface of the structure it seems that they are in conflict because each holds different cultural and ideological values which are irreconcilable. The ideological issues raised by the mainstream community, among others, is the difference in theology and interpretation to the sacred texts: the Quran and Hadith. ${ }^{33}$

In addition to theological factors, one may find another cultural belief among the Madurese community something related to the concept of self-esteem or honor deeply rooted in the Madurese culture. In the context of the conflict, the mainstream community accuses the Shi'ite community to have conducted the defamation of religion. The mainstream community will defend whatever they believe as truth by doing anything necessary, including the violent ways, to defend their selfesteem. Among the Madurese community, there is a common cultural belief that "ango'a poteya tolang etembang potea mata" (it is better to have white bone [self-esteem and honor] rather than white eyes [disgrace]). ${ }^{34}$ They defend their existing belief because by bringing different cultural belief system, the Shi'ite community is considered to have defamed the mainstream religious belief.

Viewed from the surface of the structure, again, the cultural essentialist explanation above seems to be true. Viewed from the deeper structure, however, the cultural essentialist explanation might work only at the partial periphery of the conflict. The deeper one is getting into, he/she will be struck by the fact that a broader structure is at work behind the conflict. Religious and theological argument forms only insignificant part in explaining the reality of the conflict. What is meant by structure refers to an established mode of production in the making of religious tradition. ${ }^{35}$ One important element of the established mode of production is economy: the circulation of money among the kiais/ religious men to whom the majority of Madurese pay homage and full

32 For a general survey on the perspective of cultural essentialism in analyzing religion, see John Anderson, "Does God Matter, and If So whose God? Religion and Democratization”, Democratization, vol. 11, no. 4 (2004), pp. 192-217.

33 A research project undertaken by Juhari, for instance, identifies 22 (twentytwo) theological differences between the Shi'ah and Sunni which are believed as the major factor stimulating the conflict; Juhari, "Gerakan Sosial Islam Madura”, pp. 129-31.

34 Wiyata, Carok, pp. 170-2.

35 For a good example of the use of "mode of production" in analyzing religious issues, with particular reference to social conflict, see Otto Maduro, Religion and Social Conflicts:, trans. by Robert R. Barr (Oregon: Wipf \& Stock Publishers, 1982). 
respect. This is so because the religious men are mostly responsible as the sole agent in the production of meaning among the lay community.

As the cultural festivals are held throughout Islamic calendar of the whole year, a significant amount of money is also circulated during particular months such as Rabi'ul Awwal in which everybody is celebrating the mawlid festival. ${ }^{36}$ In Sampang in particular, and Madura in general, where poverty and illiteracy are of the major issue, symbolic activities become the benchmarking pattern for religious pietism. As if there is no other alternative pattern of interpretation outside of that symbolic thread. As a result, everyone in the community, whether voluntarily or by force, would be affiliated with the standard of symbolic pietism, regardless the cost that he/she must pay. In this context, the economic cost consumed for those festivals is something else. The point here is that how to put oneself under the structure of production mode and, thus, maintaining the concept self-esteem or honor appropriately.

As an illustration, in the Sub-District Omben, where the conflict exploded, the population counts 55.201.000 people with 16.936 heads of family (Kepala Keluarga/KK). ${ }^{37}$ If one head of family has to hold every festival during the mawlid season, for instance, there will be more than 16.000 mawlid festivals during that month in one sub-district (Omben) alone! If one head of family must spend at least Rp 50.000,00 for a kiai, the mawlid festivals carried out by the whole heads of family in Omben can cost Rp. 800.000.000,00. If one head of family must pays Rp. 100.000,00 for each kiai, there will be Rp. 1.600.000.000,00 circulated among the kiais. We can imagine how many more mawlid festivals outside of the sub-district of Omben and within the district of Sampang which consists of 14 sub-districts? They will cost huge money for a single festival. ${ }^{38}$

Within the spending list, the payment for kiai usually occupies only a tiny part of total expenditure. The holders of festivals must spend some more amount of money for meals which are usually made from meat, beef or lamb, of flesh which are expensive. Therefore, it can be said that the families in Madura must spend a lot of money for religious

36 "Peringatan Maulid Nabi berlangsung Hingga Sebulan di Madura", Republika Online (27 Jan 2013), http://khazanah.republika.co.id/berita/dunia-islam/islamnusantara/13/01/27/mha92r-peringatan-maulid-nabi-berlangsung-hingga-sebulandi-madura, accessed 14 Nov 2014.

37 Juhari, "Gerakan Sosial Islam Madura", p. 100.

38 The regency of Pamekasan has 13 sub-districts; Sumenep 27 sub-districts; Bangkalan 18 sub-districts. From this fact one can imagine the massiveness of any religious festival held in Madura, especially in terms of financial expenditure. 
festivals to please guests. Behind this tradition are of course kiais, who defend the tradition sustained. It might be too naïve to argue that the kiais exist only for this purpose. Nevertheless, the association of the kiais to all religious festivals is hardly separable. Both have created the flesh-and-blood structure within the landscape of Muslim tradition in Madura. Therefore, it is not an exaggeration that the kiais are responsible for maintaining the established mode of production by incorporating the religious meanings behind all cultural values on the one side and the religious festivals on the other side.

In addition to mawlid festivals, Madura has move religious festivals in the whole year. There are Isra' Mi'raj festival, Ramadhan festival, nuzul al-Qur'an festival, Iedul Fitri and Iedul Adha festivals, and other rituals such as Slametan that invite kiais. The kiais lead the rituals or give religious sermons to the audience. This role cannot be replaced by lay persons because it needs delicate expertise owned by the kiais learnt them fin pesantren. This institution, therefore, creates the network for kiais, santris and graduates to maintain the established mode of production.

Tajul Muluk wants to oppose (such a costly tradition). Thus, the resistance from the mainstream kiais had little to do with differences in theology and religious interpretation. It has been widely acknowledged that Shi'ah followers have been there in Madura for long time. ${ }^{39}$ They both coexist and the Shi'te followers do not bother the existing mode of production in religious tradition. Furthermore, the mawlid festival is the prototype of Shi'ite festival. They are also urged by the kiais to pay homage to the Prophet's family. That is why a lot of Madurese Muslims respect Arab descendants living in the island because most of them tend to regard the later as the heirs of the Prophet, at least in biological sense.

By arguing that structure does matter in the production of conflict, it does not mean that culture does not matter. The two are deployed altogether by the agent (kiais) in maintaining the established mode of production with its role and function. Both are constructed by the kiais that forms the underpinning structure of cultural tradition in Madura, without which it can result in cultural turbulences that leads to social

39 This is so because Shi'ah in Madura and Indonesia in general does not manifest itself as the religious identity, but as a living tradition which is mixed with some Sunni tradition. The contest between the two manifests when Shi'ah becomes religious identity. For a further account on the ideological contest between Sunni and Shi'ah; Ali Hasymy, Syi'ab dan Ablussunnab: Saling Rebut Pengarub dan Kekuasaan Sejak. Awal Sejarah Islam di Kepulauan Nusantara (Surabaya: Bina Ilmu, 1983). 
disharmony. It is a matter of fact that all religious festivals are already there in the configuration of religious life in Madura before Tajul Muluk finally tried to bother the status-quo by introducing different tradition. Therefore, it is highly likely that the kiais should not be bothered by the existence of Shi'ah so long as it does not shake the mode of production.

The analysis of economic dimension to the Shi'ah-Sunni conflict in Sampang, Madura, is reminiscent of what Laurence R. Iannacone calls the rational choice approach to religion. ${ }^{40}$ In this context, Iannacone argues that:

The combined actions of religious consumers and religious producers form a religious market that, like other markets, tends toward a steadystate equilibrium. As in other markets, the consumers' freedom to choose constrains the producers of religion. A "seller" (whether of automobiles or absolution) cannot long survive without the steady support of "buyers" (whether money-paying customers, dues-paying members, contributors and coworkers, or governmental subsidizers). Consumer preferences thus shape the content of religious commodities and the structure of the institutions that provide them. These effects are felt more strongly where religion is less regulated and, as a consequence, competition among religious firms is more pronounced. In competitive environments, religions have little choice but to abandon inefficient modes of production and unpopular products in favor of more attractive and profitable alternatives. ${ }^{41}$

In relation to the Shi'ah-Sunni conflict in Sampang Madura, the existence of Shi'ah posed threats to the "steady-state equilibrium" long constructed by the actors (kiais), i.e. the mainstream Sunni. In this context, the "new market" created by Tajul Muluk endangers that equilibrium and can dissolve long-established subscription of "buyers." In other words, the mainstream actors, i.e. kiais, are afraid of losing their steady buyers, i.e. the followers of Sunni. This means that the conflict between the two is about the conflict over membership. In a

${ }^{40}$ For a general survey on the economic approach to religion, see Laurence R. Iannaccone, "Introduction to the Economics of Religion", Journal of Economic Literature, vol. 36, no. 3 (1998), pp. 1465-496; Rachel M. McCleary (ed.), The Oxford Handbook of the Economics of Religion (New York: Oxford University Press, 2011); Larry Witham, Marketplace of the Gods: How Economics Explains Religion (New York: Oxford University Press, 2010); Robert Alan Segal, The Blackewell Companion to the Study of Religion (Oxford: Blackwell Publishing, 2006), pp. 47-68.

${ }^{41}$ Laurence R. Iannaccone, "Voodoo Economics? Reviewing the Rational Choice Approach to Religion", Journal for the Scientific Study of Religion, vol. 34, no. 1 (1995), p. 77. 
The Political Economy of Sunni-Shi'ah Conflict in Sampang Madura different formulation, Hamdi-following Lewis A. Coser's theoretical framework-posits that the conflict reflects the claim of religious authority, not the truth claim in theology. ${ }^{42}$

The above excerpt also affirms that whenever religion is less regulated, it can create contest and competition. This confirms what is happening in this country that the status of religion is not clearly regulated. The constitution indeed acknowledges sixth religions to exist (Islam, Catholicism, Protestantism, Hindu, Buddhism, and Confucianism). This constitution, nevertheless, does not regulate as to what type of sect within each religion can exist. The constitution of UUD 1945 even explicitly sates that everyone is entitled to his/her right to embrace religion, and that the state guarantees that everyone may observe freely his/her own religious belief. ${ }^{43}$ The law does not regulates particular sect as forbidden. This constitution however creates ambiguity among the community. On the one hand the state does not forbid Shi'ah as it does not legalize Sunni alike, this sect does not seem to let to grow and develop further.

Using the economic approach to religion finally has something to do with the way one treats appropriately the combination of ideology and economy at one point which in turn forms structure. The combination of two has proven to be "deadly cocktail" in every part of the world. In such a combination, one should be aware of the role played by each; who play what, where, when, and how? The "deadly cocktail" in this context basically assumes the peripheral role played by the ideology, while the major driving force lies at the heart of economy. Both form the flesh-and-blood or flesh-and-bone structure which is difficult to split to each other.

\section{G. The Politics of Conflict: Hostage of Electoral Democracy}

The Sunni-Shi'ah conflict has a political dimension, not because political factors play key a role in stimulating and escalating the conflict. Rather, the freedom of religion and religious tolerance has become the hostage of electoral politics at the local level. In the context of SunniShi'ah conflict, the execution of Shi'ite followers represents the violation of the law, but the state could do nothing except taking side with the mainstream Sunni followers as the majority. As a result, the expulsion of Shi'ite followers outside of Sampang cannot be avoided. They become

${ }^{42}$ Ahmad Zainul Hamdi, "Klaim Religious Authority dalam Konflik SunniSyi ‘ Sampang Madura”, Islamica: Jurnal Studi Keislaman, vol. 6, no. 2 (2014), pp. 215-32.

${ }^{43}$ Undang-Undang Dasar (UUD) 1945, Article 28E, points (1) and (2). 


\section{Masdar Hilmy}

refugees housed in the stadium Sampang for 9 months. ${ }^{44}$ The local government as the representation of the state could do nothing when the mainstream is not willing to accept the coming of Shi'ite followers back home. More tragically, it has facilitated the expulsion of Shite refugees into Sidoarjo.

In an electoral democracy like in Indonesia the violation of freedom of religion conducted by non-state actors can be seen as the act of omission by the state. The case of Sunni-Shi'ah conflict in Sampang seems to justify the violation of this type. Indeed the state is not involved in the direct violation of freedom of religion. The state is inability to protect the rights of minority group to observe and exercise their religious belief can be considered as the violation of the law. The siding of the state with the majority group in persecuting the minority group can increase the degree of violation from the act of omission to the act of commission where the state involvement in the exacerbation of conflict is more visible. The Sunni-Shi'ah conflict in Sampang Madura can be seen from this perspective.

The political aspect of the conflict starts from what is termed as "the law of electoral exchange." There is no direct transaction between the ruling elite and the ruled. The association between the voters and the voted can shape the state policy in favor of the interests of the voters. In this context, Kaare Strom and Wolfgang C. Müller argue that "Electoral exchange provides party leaders with votes, which they can cash in for policy or office benefits. Votes are the currency of democratic politics, but their use and value depend on the rules by which other goods may be purchased. A variety of political institutions shape the conversion of votes into spoils and policy influence."45

Madura in general, with particular reference to Sampang, has given significant contribution to the victory of the current governor of East Java, the pair Soekarwo-Saifullah Yusuf, in the first and second local elections in 2008 and 2013. During the first gubernatorial election in 2008, the Supreme Court of Constitution decided to repeat the election three times in Sampang due to the accused violation done by the pair Soekarwo-

${ }^{44}$ Saiful Bahri, "Kisah Miris Pengungsi Syiah Sampang Sambut Ramadan", Tempo (20 Jul 2015), http:/ / ramadan.tempo.co/read/news/2015/06/20/151676713/ kisah-miris-pengungsi-syiah-sampang-sambut-ramadan, accessed 16 Nov 2015.

45 Wolfgang C. Müller and Kaare Strom, Policy, Office, or Votes? How Political Parties in Western Europe Make Hard Decisions (New York: Cambridge University Press, 1999), p. 21. 
The Political Economy of Sunni-Shi'ah Conflict in Sampang Madura

Saifullah Yusuf. In both elections the pair Soekarwo-Saifullah Yusuf was finally decided by the Komisi Pemilihan Umum (KPU, Commission of General Election) as the winner over the pair Khofifah Indar-ParawansaMujiono. ${ }^{46}$ The success story for the pair Soekarwo-Saifullah Yusuf repeats in the 2013 gubernatorial election which led them win over the pair Khofifah Indar Parawansa-Herman Surjadi Sumawiredja.

In regards to the electoral contest, the question is: what is the role played by the local kiais and pesantren in both gubernatorial elections? It is undeniable that kiais and their institution, pesantren, have been the major reference in general election for the community in Madura. ${ }^{47}$ Different from Java where the influence of kiais in politics has been declining steadily, the kiais in Madura are still effective vote-getters in electoral politics. This is understandable due to the fact that the political culture in Madura adopts patrimonialistic pattern. In this situation, the relationship between the kiai and santri-as well as pesantren graduatesforms patron-client relationship which assumes dependency upon one to another. ${ }^{48}$ The significance of kiai in Madura is the explanation why this island has served as the "storehouse of votes" for all politicians during the electoral contest.

In addition to electoral politics, the pair Soekarwo-Saifullah Yusuf has effectively utilized the bureaucracy machinery in the structure of local government. The case of Sunni-Shi'ah conflict in Sampang has shown clearly that all bureaucratic apparatus - from the Regent, the head of police, the domestic court, the Chairman of parliament, the head of Ministry for religious affairs, and the head of Bakesbangpol-has been unified under the single interest of the state at the upper level, i.e. the provincial government. It is highly unlikely that each of these can negotiate with their superior in terms of just law enforcement. Their institutional policies will reflect the wider interest of esprit-de-corps: the state bureaucracy.

From the description above, it is undeniable that the significance of kiai in local politics of Madura has paved the way for victory the pair Soekarwo-Saifullah Yusuf as the governor and vice governor of East

${ }^{46}$ Agus Setiawan, "KPU Jawa Timur Menangkan Karsa", Antaranews (11 Dec 2008), http://www.antaranews.com/berita/123586/kpu-jawa-timur-menangkan-karsa, accessed 15 Oct 2014.

47 “Ulama Masih Jadi Rujukan Pemilih di Jatim”, Kompas (27 Aug 2013), http:// regional.kompas.com/read/2013/08/27/0958561/Ulama.Masih.Jadi.Rujukan.Pemilih. di.Jatim, accessed 29 Oct 2015.

48 Jatim, "Konflik Sunni-Syi'ah", p. 84. 
Java. As a part of political "compensation," the governor will always take seriously all kiais grievances, including their interests in terms of Sunni-Shi'ah conflict in Sampang. This means that whoever becomes the majority in Madura will decide the ending result of the conflict. As we have already known, the result tends to be Sunni kiai-heavy, in the sense that politics is the main reason why the government or the state has opted to take side with the local Sunni kiais rather than with the Shi'ah community. The combination of local or religious leaders such as kiai and the government agents in electoral politics has formed what one refers to as "the marriage convenience" between the two.

\section{H. Concluding Remarks}

This paper has demonstrated that the Sunni-Shi'ah conflict in Sampang Madura has a strong political-economy dimension. The conflict can be seen as the way the local elites maintain the established mode of production: economy, politics, culture, and symbols. This mode of production has created the state of equilibrium in the society. In this case, kiais are the "sellers" whose religious ideas and practices are bought by the "buyers," i.e. the lay community. All religious festivals are among the "products" that the kiais sell to the community. It is within this context that the existence of Shi'ah community in Sampang is regarded by the mainstream Sunni community as a threat to their long domination over the socio-political structure in Madura because Tajul Muluk as the leader of Shi'ah community offers a different product with more efficient way in holding festival celebration within one village mosque.

Furthermore, the conflict is part of a larger scheme of electoral politics at the expense of the state's omission act towards the violation of freedom of religion which in the end favors the mainstream Sunni community. The conflict justifies the "electoral exchange" theory between the state apparatus and kiais as non-governing elite in Madura. The reason for the state's political favoritism is clear: kiais in Madura are considered as the vote-gatherers who have paved the way for the victory of existing governing elites, either at the provincial or at the local level. Despite the fact that politics is not the driving factor behind the conflict, it leads to an unjust treatment towards the Shi'ah community as the victim of conflict. 
The Political Economy of Sunni-Shi'ah Conflict in Sampang Madura

\section{BIBLIOGRAPHY}

Anderson, John, "Does God Matter, and If So whose God? Religion and Democratization", Democratization, vol. 11, no. 4, 2004, pp. 192-217 [http://dx.doi.org/10.1080/135103404000236817].

Arifin, Syamsul and Muhammad Junaedi, "Konstruksi Sosial Masyarakat Syi'ah dan Sunni di Sampang, Madura", in Hak Asasi Manusia untuk. Kebebasan Beragama dan Berkeyakinan di Indonesia: Keniscayaan, Kenyataan dan Penguatan, ed. by Syamsul Arifin, Madang: Pusat Studi Agama dan Multikulturalisme [PUSAM] Program Pascasarjana UMM, 2014.

Bahri, Saiful, "Kisah Miris Pengungsi Syiah Sampang Sambut Ramadan”, Tempo Ramadan, 20 Jul 2015, http://ramadan.tempo.co/read/ news/2015/06/20/151676713/kisah-miris-pengungsi-syiahsampang-sambut-ramadan, accessed 16 Nov 2015.

Biro Pusat Statistik, Sampang dalam Angka, Sampang: BPS Kab. Sampang, 2008.

Hamdi, Ahmad Zainul, "Klaim Religious Authority dalam Konflik Sunni-Syi'i Sampang Madura", Islamica: Jurnal Studi Keislaman, vol. 6, no. 2, 2014, pp. 215-31 [http://dx.doi.org/10.15642/ islamica.2012.6.2.215-231].

Hasymy, Ali, Syi'ab dan Ablussunnah: Saling Rebut Pengaruh dan Kekuasaan Sejak. Awal Sejarab Islam di Kepulauan Nusantara, Surabaya: Bina Ilmu, 1983.

Iannaccone, Laurence R., "Voodoo Economics? Reviewing the Rational Choice Approach to Religion", Journal for the Scientific Study of Religion, vol. 34, no. 1, 1995, pp. 76-88 [http://dx.doi.org/10.2307/1386524].

----, "Introduction to the Economics of Religion", Journal of Economic Literature, vol. 36, no. 3, 1998, pp. 1465-95.

Jatim, “Konflik Sunni-Syi'ah Sampang Madura: Telaah Fenomenologis terhadap Patrimonialisme Budaya Politik", Master Thesis, Surabaya: UIN Sunan Ampel Surabaya, 2014, http:/ / digilib.uinsby.ac.id/1328/, accessed 28 Sep 2015.

Jonge, Huub de, Garam, Kekerasan dan Aduan Sapi: Esai-esai tentang Oang Madura dan Kebudayaan Madura, Yogyakarta: LKiS Group, 2012.

Juhari, Imam Bonjol, "Gerakan Sosial Islam Madura: Studi Gerakan Protes Islam Sunni terhadap Ideologi Syi'ah di Sampang”, Master Thesis, Surabaya: UIN Sunan Ampel Surabaya, 2014, http:// digilib. 
Masdar Hilmy

uinsby.ac.id/1213/, accessed 28 Sep 2015.

"Laporan Investigasi dan Pemantauan Kasus Syi'ah Sampang", Report, Surabaya: Kontras, http://kontras.org/data/Laporan\%20 Investigasi\%20Syiah\%20di\%20Sampang.pdf, accessed 17 Sep 2015.

Kuntowijoyo, Perubahan Sosial dalam Masyarakat Agraris Madura 1850-1940, Jogjakarta: Mata Bangsa, 2002.

Maduro, Otto, Religion and Social Conflicts, trans. by Robert R. Barr, Oregon: Wipf \& Stock Publishers, 1982.

McCleary, Rachel M. (ed.), The Oxford Handbook of the Economics of Religion, New York: Oxford University Press, 2011.

Muliono, Slamet, Syi'ab dan Masyarakat Lokal Sampang: Studi tentang Militansi Pengungsi Syi'ah dan Dinamika Masyarakat Lokal Sampang, Unpublished research report, Surabaya: UIN Sunan Ampel Surabaya, 2014.

Müller, Wolfgang C. and Kaare Strom, Policy, Office, or Votes? How Political Parties in Western Europe Make Hard Decisions, New York: Cambridge University Press, 1999.

Pareto, Vilfredo, The Rise and Fall of Elites: an Application of Theoretical Sociology, New Brunswick and London: Bedminster Press, 1968.

"Peringatan Maulid Nabi berlangsung Hingga Sebulan di Madura", Republika Online, 27 Jan 2013, http://khazanah.republika.co.id/ berita/dunia-islam/islam-nusantara/13/01/27/mha92r-peringatanmaulid-nabi-berlangsung-hingga-sebulan-di-madura, accessed 14 Nov 2014.

Rozaki, Abdur, Menabur Kharisme Menuai Kuasa: Kiprab Kiai dan Blater sebagai Rezim Kembar di Madura, Yogyakarta: Pustaka Marwa, 2004.

----, "The Social Origins and Political Power of Blaters (Thugs) in Madura", Kyoto Review of Southeast Asia, 12 Nov 2009, http:// kyotoreview.org/issue-11/the-social-origins-and-political-powerof-blaters-thugs-in-madura/, accessed 28 Oct 2015.

Segal, Robert Alan, The Blackwell Companion to the Study of Religion, Oxford \& Melbourne: Blackwell Publishing, 2006.

Setiawan, Agus, "KPU Jawa Timur Menangkan Karsa”, Antaranews, 11 Dec 2008, http:/ / www.antaranews.com/berita/123586/kpu-jawatimur-menangkan-karsa, accessed 15 Oct 2014.

"Ulama Masih Jadi Rujukan Pemilih di Jatim”, Kompas, 27 Aug 2013, http://regional.kompas.com/read/2013/08/27/0958561/Ulama. 
The Political Economy of Sunni-Shi'ah Conflict in Sampang Madura Masih.Jadi.Rujukan.Pemilih.di.Jatim, accessed 29 Oct 2015.

Weber, Max, On Charisma and Institution Building, ed. by S.N. Eisenstadt, Chicago: The Univ. of Chicago Press, 1968.

Witham, Larry, Marketplace of the Gods: How Economics Explains Religion, New York: Oxford University Press, 2010.

Wiyata, A. Latief, Carok: Konflik Kekuasaan dan Harga Diri Orang Madura, Yogyakarta: LKiS, 2002. 